\title{
IMPLEMENTASI PENGALOKASIAN DANA PAJAK (EARMARKING TAX) DARI PENERIMAAN PAJAK ROKOK TERHADAP UPAYA KESEHATAN MASYARAKAT DI PROVINSI SULAWESI UTARA
}

\author{
Damayanti Rante Tambing', David Saerang², Heince Wokas ${ }^{3}$ \\ 1.2.3 Fakultas Ekonomi dan Bisnis, Jurusan Akuntansi, Universitas Sam Ratulangi, Jl. Kampus Bahu, Manado, \\ 95115, Indonesia \\ E-mail : damaytambing@yahoo.co.id
}

\begin{abstract}
The cigarette tax is applied in the province of North Sulawesi in 2014. Cigarette tax is a regulate tax that is specific to the health, then the purpose of applying cigarette tax is to protect the public against the dangers of cigarettes. Therefore, cigarette tax in earmarking tax policy is allocated at least 50\% for public health service. The purpose of this study is to analyze the implementation of earmarking tax of Cigarettes tax to public health services in North Sulawesi Province has been in accordance with applicable legislation. The method used is descriptive qualitative. The results of this study can be seen that for the year 2016, earmarking tax policy of tobacco tax has not been applied in accordance with the appropriate. This is because spending on public health efforts has not reached the minimum value of 50\% of tax revenues for provinces. Earmarking tax in North Sulawesi province runs with revenue and expenditure budget system (APBD), which is implemented through the regional public treasury account (RKUD) in terms of income and expenditure. Dinas Kesehatan as an agency that budgeted for public health effort would improve public health service standard by maximizing spending for the designation. Agencies related to the cigarette tax budgeting policy would prescribe standard operating procedures so that control over these policies can be done as appropriate
\end{abstract}

Keywords: Earmarking tax policy, cigarette tax.

\section{PENDAHULUAN}

\subsection{Latar Belakang Penelitian}

Kebijakan desentralisasi fiskal merupakan dukungan kepada pemerintah daerah untuk pelayanan publik diwujudkan dengan mentransfer dana ke daerah sesuai dengan peraturan perudangan-undangan yang berlaku, dalam hal ini yaitu Undang-Undang Nomor 28 Tahun 2009 tentang Pajak Daerah dan Retribusi Daerah. Melalui peraturan perundangan tersebut diharapkan daerah dapat lebih mendorong peningkatan pelayanan kepada masyarakat dan kemandirian daerah.

Berdasarkan Undang-Undang Nomor 28 Tahun 2009, Pajak Rokok yang disahkan pada 18 Agustus 2009 merupakan dana transfer untuk pemerintah daerah. Pajak rokok masuk dalam kategori pajak provinsi yang nantinya akan menjadi salah satu sumber pendapatan asli daerah. Provinsi Sulawesi Utara pajak rokok mulai diberlakukan terhitung mulai dari tahun 2014. Berikut ini adalah penerimaan Pajak Rokok oleh Dinas Pendapatan Daerah Provinsi Sulawesi Utara pada tahun 2014-2015:

Tabel 1. Target dan Realisasi Pajak Rokok tahun 2014-2015

\begin{tabular}{cccc}
\hline Tahun & Target & Realisasi & \% \\
\hline $\mathbf{2 0 1 4}$ & 96.000 .000 .000 & 69.377 .472 .983 & $72,27 \%$ \\
$\mathbf{2 0 1 5}$ & 98.560 .000 .000 & 112.412 .415 .261 & $114,05 \%$ \\
\hline
\end{tabular}


Undang-Undang nomor 28 Tahun 2009 tentang Pajak Daerah dan Retribusi Daerah, terdapat kebijakan baru yang memuat tentang pengalokasian dana pajak atau earmarking tax. Pengalokasian dana pajak atau earmarking tax adalah pengalokasian sejumlah penerimaan pajak untuk mendanai sektor pajak tertentu sesuai dengan pajak yang dipungut. Terdapat alokasi (earmark) paling sedikit 50\% (persen) dari hasil penerimaan pajak rokok, digunakan untuk mendanai pelayanan kesehatan masyarakat. Dibidang kesehatan, keputusan ini diambil sebagai langkah pengimbangan antara konsumsi rokok dengan kesehatan masyarakat. Kebijakan pengalokasian dana pajak atau earmarking tax dari penerimaan pajak rokok diberlakukan di provinsi Sulawesi Utara terhitung mulai dari tahun 2015.

Permasalahan dibidang kesehatan masih cukup banyak baik pada Skala Nasional maupun Skala Daerah. Pemerintah Daerah Provinsi Sulawesi Utara masih terus berusaha meningkatkan pelayanan kesehatan dengan cara menerapkan berbagai kebijakan dalam kesehatan. Pengalokasian dana pajak atas pajak rokok dimaksudkan untuk mendanai berbagai macam sarana dan prasarana pelayanan kesehatan masyarakat. Jika di bandingkan dengan berbagai masalah kesehatan masyarakat maka fasilitas pelayanan kesehatan masyarakat dapat dikatakan belum memadai untuk melayani masyarakat yang membutuhkan pelayanan kesehatan.

Secara umum hampir sepertiga penduduk umur $\geq 10$ tahun di Sulawesi Utara adalah perokok dengan rerata jumlah rokok yang dihisap 10 batang. Kawasan Tanpa Rokok, yang selanjutnya disingkat KTR, adalah ruangan atau area yang dinyatakan dilarang untuk kegiatan merokok atau kegiatan memproduksi, menjual, mengiklankan, dan/atau mempromosikan produk tembakau. Pengalokasian dana pajak rokok pun turut berperan dalam pengadaan kawasan tanpa rokok ini. Oleh karena itu, dengan diterapkannya kebijakan pengalokasian dana pajak atau earmarking tax atas penerimaan pajak rokok sekiranya dapat turut berperan dalam pendanaan sarana dan prasarana kesehatan masyarakat dan pengadaan kawasan tanpa rokok (KTR).

\subsection{Tujuan Penelitian}

Untuk menganalisis implementasi pengalokasian dana pajak atau earmarking tax dari penerimaan Pajak Rokok terhadap pelayanan kesehatan masyarakat di Provinsi Sulawesi Utara telah sesuai dengan peraturan perundang-undangan yang berlaku.

\section{TINJAUAN PUSTAKA}

\subsection{Konsep Akuntansi}

Akuntansi merupakan sistem informasi yang menghasilkan informasi keuangan kepada pihak-pihak yang berkepentingan mengenai aktifitas ekonomi dan kondisi suatu perusahaan (Rudianto, 2012:4). Selain itu terdapat pengertian lain mengenai pengertian akuntansi menurut Pura (2013:4) yaitu, "seperangkat pengetahuan yang mempelajari perekayasaan dalam penyediaan jasa, yang berupa informasi keuangan kuantitatif dari suatu unit organisasi dan cara penyampaian (pelaporan) informasi tersebut kepada pihak yang berkepentingan untuk dijadikan dasar pengambilan keputusan ekonomi”. Dengan demikian akuntansi adalah proses pencatatan, penggolongan, peringkasan dan penyajian dengan cara-cara tertentu terhadap transaksi keungan yang terjadi dalam perusahaan atau organisasi lainnya serta interprestasinya terhadap hasilnya.

\subsection{Akuntansi Keuangan Daerah}

Menurut Halim (2013:41) Akuntansi keuangan daerah adalah proses mengindentifikasi, pengukuran, pencatatan dan pelaporan transaksi ekonomi tentang keuangan dari entitas pemerintah daerah Kabupaten, Kota atau Provinsi yang dijadikan 
sebagai informasi dalam rangka pengambilan keputusan ekonomi oleh pihak-pihak eksternal entitas pemerintah daerah.

\subsection{Pajak Daerah}

Karakteristik Bird mengenai pajak daerah bermakna bahwa pajak daerah sesungguhnya dipungut, dikumpulkan, ditentukan tarif dan wajib pajaknya oleh pemerintah daerah setempat. Karakteristik tidak jauh berbeda dengan ciri pajak daerah yang ditulis oleh Samudra, antara lain :

1.Pajak daerah dapat berasal dari pajak asli daerah maupun pajak maupun pajak Negara yang diserahkan kepada daerah sebagai pajak daerah.

2.Pajak daerah yang dipungut oleh daerah terbatas didalam wilayah administratif yang dikuasainya.

3.Hasil pungutan pajak daerah dipergunakan untuk membiayai urusan rumah tangga daerah atau untuk membiayai pengeluaran daerah sebagai badan hukum.

4.Pajak daerah dipungut oleh pajak daerah berdasarkan Peraturan Daerah (Perda) maka sifat pemungutan pajak daerah dapat dipaksakan kepada masyarakat yang wajib membayar dalam lingkungan administratif kekuasaannya. (Samudra, 2004)

\subsection{Dana Bagi Hasil Provinsi}

Bagi Hasil Pajak merupakan salah satu kebijakan pemerintah dalam pelaksanaan perimbangan keuangan pusat dan daerah. Kebijakan perimbangan keuangan, sebagai bagian dari skema desentralisasi fiskal, memiliki paling kurang dua target utama, yakni mencukupkan pembiayaan daerah dalam mengurus limpahan kewenangan yang diterimanya dan memeratakan kemampuan/ kapasitas fiskal (fiscal capacity) antar daerah berdasar derajat kebutuhan (fiscal need) masing-masing (www.kppod.org).

\subsection{Pengalokasian Dana Pajak}

Pengalokasian dana pajak atau earmarking merupakan praktik penganggaran yang didedikasikan oleh pajak umum atau penerimaan lainnya untuk program atau tujuan tertentu. Earmarking atau earmarked sering dikaitkan dengan konteks perpajakan, sehingga kemudian muncul istilah Earmarking taxes. Clague and Gordon (1939) menyatakan, tax earmarking adalah beberapa pajak yang sengaja dipisahkan dari pendapatan secara keseluruhan dan hanya bisa digunakan untuk program-program khusus pemerintah dan digunakan sepenuhnya untuk program tersebut.

\subsection{Pajak Rokok}

Pajak Rokok adalah pungutan atas cukai rokok yang dipungut oleh instansi pemerintah yang berwenang memungut cukai bersamaan dengan pemungutan cukai rokok. Pajak Rokok yang dipungut oleh instansi pemerintah nantinya akan disetor ke rekening kas umum provinsi secara proporsional berdasarkan jumlah produk.

Berdasarkan fungsinya yang bersifat Regurelend (mengatur) yang terkhusus pada kebijakan Pemerintah terhadap kesehatan maka Penerapan Pajak Rokok adalah untuk melindungi masyarakat terhadap bahaya rokok. Penerapan Pajak Rokok sebesar 10 persen dari nilai cukai juga dimaksudkan untuk memberikan optimalisasi pelayanan pemerintah daerah dalam menjaga kesehatan masyarakat.

\subsection{Kebijakan Publik untuk Upaya Kesehatan Masyarakat}

Kebijakan publik adalah suatu rangkaian pilihan-pilihan yang saling berhubungan yang dibuat oleh lembaga atau pejabat pemerintah, seperti pertahanan keamanan, energi, kesehatan, pendidikan, kesejateraan masyarakat, kriminalitas, perkotaan, dan lain-lain. 
Kebijakan kesehatan dapat meliputi kebijakan publik dan swasta tentang kesehatan. Kebijakan kesehatan diasumsikan untuk merangkum segala arah tindakan (dan dilaksanakan) yang mempengaruhi tatanan kelembagaan, organisasi, layanan dan aturan pembiayaan dalam system kesehatan (Kent Buse, 2005).

\subsection{Penelitian Terdahulu}

Yudha Agung Permana (2016), dengan judul : Pelaksanaan Pemungutan Pajak Rokok. Hasil penelitian yaitu dalam proses pemungutan Pajak Rokok Provinsi Lampung, pemungutan dilakukan dengan cara wajib pajak menyelesaikan administrasi kepada kantor pelayanan dan pengawasan bea dan cukai tipe madya pabean b bandar lampung berupa berkas SPPR.

Mita Vajar Indah (2015), dengan judul : Pelaksanaan Alokasi Dana Bagi Hasil Pajak Rokok Untuk Pelayanan Kesehatan Masyarakat (Studi tentang Implementasi Pasal 31 Undang-Undang Nomor 28 Tahun 2009 tentang Pajak Daerah dan Retribusi Daerah di Kabupaten Blitar). Hasil penelitian yaitu Dinas Kesehatan Kabupaten Blitar telah melaksanakan alokasi dana bagi hasil pajak rokok untuk pelayanan kesehatan masyarakat dan penegakan hukum sesuai amanat Pasal 31 Undang-Undang No. 28 Tahun 2009. Rencana Kegiatan Anggaran (RKA) Dinas Kesehatan Kabupaten Blitar Tahun 2014 disusun sebelum dilaksanakan. Pelaksanaan Pasal 31 Undang-Undang No. 28 Tahun 2009 tentang Pajak Daerah dan Retribusi Daerah terkait alokasi dana bagi hasil pajak rokok untuk pelayanan kesehatan, menurut penulis belum efektif.

Novia Ratna Maharani (2014), dengan judul : Analisis Pendapatan Bagi Hasil Pajak Provinsi Sebagai Upayah Peningkatan Pembangunan Daerah (Studi Pada Dinas Pendapatan Daerah dan Badan Pengolah Keuangan dan Aset Daerah Kabupaten Kediri Tahun 2008-2013. Hasil penelitian yaitu Kenaikan dan penurunan bagi hasil yang mempengaruhi tercapainya target disebabkan perubahan pendapatan Pajak Provinsi di Kabupaten Kediri dan kabupaten atau kota lain di Jawa Timur karena hasil pendapatan dari kabupaten/kota lain masuk dalam perhitungan Bagi Hasil Pajak Provinsi sesuai Peraturan Daerah yang berlaku.

Poetri Mutiara Bella (2010), dengan judul : Analisis Earmarking tax atas Pajak Kendaraan Bermotor. (Studi earmarking tax di DKI Jakarta). Hasil penelitian yaitu ) justifikasi penerapan kebijakan earmarking tax atas PKB meliputi beberapa alasan yaitu penerapan prinsip manfaat, permasalahan kemacetan di DKI Jakarta, adanya kepastian sumber pendanaan

Suki Hariawan (2011), dengan judul : Analisis Pengalokasian Anggaran untuk Penerangan Jalan Sebelum dan Sesudah Dikeluarkannya Kebijakan Earmarking tax atas Pajak Penerangan Jalan di DKI Jakarta. Hasil penelitian yaitu Pengalokasian anggaran untuk penerangan jalan oleh pemerintah DKI Jakarta sebelum dikeluarkannya kebijakan earmarking tax atas pajak penerangan jalan pada tahun 2007-2010 telah mencapai presentase rata-rata lebih dari 50\% namun sumber anggaran tersebut masih berasal dariAPBD DKI Jakarta.

\section{METODE PENELITIAN}

\subsection{Jenis Penelitian}

Berdasarkan tujuannya, penelitian ini termasuk dalam penelitian deskriptif (descriptive research). Menurut Suharsimi Arikanto (2013:174) metode deskriptif adalah penelitian yang dimaksudkan untuk menyelidiki keadaan, kondisi atau hal lain-lain yang sudah disebutkan yang hasilnya dipaparkan dalam laporan penelitian. 


\subsection{Tempat dan Waktu Penelitian}

Penelitian ini dilakukan di Badan Pengolah Pajak dan Retribusi Daerah Provinsi Sulawesi Utara dan Dinas Kesehatan Daerah Provinsi Sulawesi Utara. Periode waktu penelitian dimulai pada bulan April sampai Mei 2017.

\subsection{Prosedur Penelitian}

1. Mengajukan Permohonan Penelitian

2. Disposisi Pimpinan Instansi

3. Pengumpulan Data

4. Analisis Data Penelitian dan Pembahasan

5. Menarik Kesimpulan

\subsection{Metode Pengumpulan Data}

\section{Jenis Data}

a. Data Kuantitatif adalah data yang disajikan dalam bentuk skala numerik (angka). Namun dalam statistik, semua data kualitatif umumnya dikuantitatifkan agar dapat diproses lebih lanjut. Data Kuantitatif yang digunakan dalam penelitian ini adalah data Penerimaan pajak rokok di Dinas Pendapatan Daerah Provinsi Sulawesi Utara dan Belanja untuk untuk program upaya pelayanan kesehatan di Dinas Kesehatan Provinsi Sulawesi Utara.

b. Data Kualitatif merupakan data yang tidak dapat diukur dalam skala numerik atau data yang disajikan dalam bentuk deskriptif atau bentuk uraian. Dalam penelitian ini akan menggunakan data kualitatif dari hasil wawancara dengan beberapa pihak pemerintah.

2. Sumber Data

a. Data Primer yaitu data yang langsung dari objek penelitian atau tempat penelitian (pihak internal instansi) berupa data dan informasi yang relevan dengan penelitian, lewat wawancara langsung dan pembagian kuisioner.

b. Data Sekunder merupakan data yang dikumpulkan oleh lembaga pengumpul data dan yang telah dipublikasikan kepada masyarakat pengguna data.

3. Teknik Pengumpulan Data

Menurut Sugiyono (2013:2) teknik pengumpulan data merupakan langkah yang paling straregis dalam penelitian, karena tujuan utama dari penelitian adalah mendapatkan data. Teknik Pengumpulan data yang dilakukan terdiri dari beberapa tahap yaitu:

a. Penelitian Lapangan (field research), merupakan kegiatan kunjungan serta kegiatan pengumpulan data ditempatkan atau objek yang memiliki sumber data yang sesuai dengan penelitian, data diperoleh melalui cara wawancara dan documenter.

b. Penelitian Kepustakaan (library research), merupakan cara pengumpulan yang dilakukan dengan mengumpulkan data dari teori-teori yang diperoleh dan dipelajari dari buku-buku, literatur, jurnal, serta bahan-bahan informasi lainnya sesuai dengan masalah yang diteliti sebagai landasan pemikiran teoritis bagi penulis dalam membahas penelitian

\subsection{Metode Analisis}

Penelitian ini menganalisis :

1. Peraturan tentang kebijakan alokasi dana pajak atau earmarking tax dari pajak rokok untuk upaya kesehatan masyarakat yang berlaku di Provinsi Sulawesi Utara.

2. Penerimaan pajak rokok dan pengeluaran belanja untuk program pendanaan upaya kesehatan masyarakat. Melalui perbandingan yang dilakukan antara penerimaan pajak 
dan pengeluaran belanja akan diperoleh kesimpulan tentang sesuai tidaknya kebijakan tersebut diterapkan di Provinsi Sulawesi Utara.

\section{HASIL PENELITIAN DAN PEMBAHASAN 4.1 Gambaran Umum Objek Penelitian}

Provinsi Sulawesi Utara terletak di wilayah paling utara pulau Sulawesi, dan dikenal sebagai provinsi kepulauan. Provinsi Sulawesi Utara dengan Ibukota Manado terletak pada $0^{\circ} 15^{\prime} 5^{\circ} 34^{\prime}$ Lintang Utara dan $123^{\circ} 07-27^{\circ} 10^{\prime}$ Bujur Timur. Visi Provinsi Sulawesi Utara "Terwujudnya Sulawesi Utara yang berdikari dalam ekonomi, berdaulat dalam pemerintahan dan politik, serta berkepribadian dalam berbudaya."

Badan Pengelola Pajak dan Retribusi Daerah (BPPRD) merupakan badan yang dibentuk karena adanya desentralisasi fiskal yang mengharuskan daerah menangani sendiri urusan rumah tangganya. Pada tahun-tahun sebelumnya, BPPRD Sulawesi Utara dikenal sebagai Dinas Pendapatan Daerah Sulawesi Utara. Namun, seiring dengan berjalannya waktu terjadi penyempurnaan dalam organisasi dam fungsi aparatur pemerintahan di Tingkat Provinsi maka pada tahun 2017 Dinas Pendapatan diubah menjadi Badan Pengelola Pajak dan Retribusi Daerah.

Dinas Kesehatan adalah unsur pembantu pemerintah Provinsi Bidang Kesehatan. Sebagai unsur pembantu pemerintah provinsi, maka segala kebijakan yang berkaitan dengan Tugas dan fungsi Dinas Kesehatan saat ini ialah melaksanakan tugas-tugas desentralisasi, dekonsentralisasi dan tugas pembantuan. Pelaksanaan Kegiatan teknis program-program kesehatan di daerah tetap mengacuh pada ketentuan perundangan pemerintah RI yaitu Undang-undang Kesehatan, Peraturan Pemerintah dibidang Kesehatan, Peraturan Menteri serta petunjuk pelaksanaan kegiatan teknis yang ditetapkan oleh Kementerian Kesehatan.

\subsection{Hasil Penelitian}

\subsubsection{Pengaturan Alokasi Dana Pajak Rokok}

Dalam Peraturan Gubernur Sulawesi Utara nomor 16 tahun 2016 Tentang Penetapan Alokasi Sementara Bagi Hasil Pajak Provinsi Kepada Pemerintah Kabupaten/Kota seProvinsi Sulawesi Utara dari Pajak rokok, pada ayat yang ketiga mengatakan bahwa:

"Baik bagian Provinsi dan bagian Kabupaten/Kota dialokasikan paling sedikit 50\% untuk mendanai pelayanan kesehatan masyarakat dan penegakan hukum oleh aparat yang berwenang"

Rancangan Anggaran Pendapatan dan Belanja Daerah (APBD) merupakan tempat diaturnya berbagai kegiatan pendapatan dan pengeluaran untuk belanja di Sulawesi Utara, termasuk penerimaan pajak rokok yang sudah dibagi hasilkan. Alokasi pajak rokok untuk mendanai upaya kesehatan masyarakat belanjanya diatur oleh Dinas Kesehatan baik provinsi maupun kabupaten/kota. Pengaturan rancangan anggaran untuk belanja tersebut diatur oleh masing-masing SKPD, sehingga akan terlihat besaran nominal dalam struktur APBD untuk belanja upaya kesehatan masyarakat. Dalam membiayai biaya tersebut juga menggunakan dana yang telah dirancang dalam APBD. Badan Pengolah Keuangan dan Barang Milik Daerah (BPK-BMD) akan menyalurkan dana untuk belanja kepada SKPD-nya yang didasarkan pada jumlah anggaran untuk SKPD.

\subsubsection{Penerimaan Pajak Rokok Provinsi Sulawesi Utara dan Belanja Untuk Pendanaan Upaya Kesehatan Masyarakat}

Pemasukan PAD tahun 2016 dari Pajak Rokok dapat dilihat dalam tabel berikut : 
Tabel 3. Penerimaan Pajak Rokok Prov. Sulawesi Utara Tahun 2016

\begin{tabular}{cccc}
\hline Tahun & Target & Realisasi & \% \\
\hline $\mathbf{2 0 1 6}$ & 127.900 .000 .000 & 107.158 .711 .896 & $83,78 \%$ \\
\hline
\end{tabular}

Sumber : Badan Pengolah Pajak dan Retribusi Prov. Sulawesi Utara

Pendanaan upaya kesehatan masyarakat di Provinsi Sulawesi Utara merupakan salah satu kegiatan belanja langsung yang diatur dalam rencangan APBD dan dijadikan prioritas yang terutama dalam hal pemasukan dana pajak rokok. Dalam hal mengatur belanja langsung untuk upaya kesehatan masyarakat tingkat provinsi dilakukan oleh Dinas Kesehatan daerah provinsi Sulawesi Utara Upaya kesehatan masyarakat dalam kegiatan belanjanya didasarkan pada kebutuhan dari daerah untuk pembiayaannya, jadi besaran dana yang dikeluarkan adalah nominal yang dibutuhkan daerah tersebut. Berikut ini merupakan jumlah pengeluaran untuk pendanaan upaya kesehatan masyarakat di Provinsi Sulawesi Utara tahun 2016:

\section{Tabel 4. Pengeluaran Belanja untuk Pendanaan Upaya Kesehatan Masyarakat tahun} 2016

Uraian Jumlah Anggaran Realisasi Keuangan

\begin{tabular}{|c|c|c|}
\hline Program Peningkatan Kapasitas Sumber daya Aparatur & Rp.42.633.770 & Rp. 34.379.000 \\
\hline $\begin{array}{l}\text { Program Penyelenggaraan } \\
\text { kenegaraan/kedaerahaan }\end{array}$ & Rp218.868.000 & Rp. 206.254.400 \\
\hline Program Obat dan Pembekalan Kesehatan & Rp. 1.244.429.040 & Rp. 923.554.075 \\
\hline Program Upaya Kesehatan Masyarakat & Rp. 341.142.100 & Rp. 264.347.700 \\
\hline Program Promosi Kesehatan dan Pemberdayaan Masyarakat & Rp. 697.182 .500 & Rp. 634.933.100 \\
\hline Program Perbaikan Gizi Masyarakat & Rp. 302.111 .000 & Rp. 266.232.700 \\
\hline Program Pengembangan Lingkungan Sehat & Rp. 297.285 .000 & Rp. 295.997 .800 \\
\hline Program Pencegahan dan Penanggulangan Peny & Rp. 1.814 .275 .400 & Rp. 1.687 .660 .800 \\
\hline Program Standarisasi Pelaya & 3.400 & Rp. 332. \\
\hline Program Peningkatan pela & Rp. 7 & Rp. $433 .($ \\
\hline Program Peningkatan Pela & Rp. 7 & Rp. 612.1 \\
\hline Program Peningkatan Keselamatan Ibu Melahirkan dan Anak & Rp. 727.168.000 & Rp. 634.780 .668 \\
\hline Program Penanggulangan Wabah dan Bencana & Rp. 72.108.000 & Rp. 71.043 .700 \\
\hline Program Keselamatan Haji & Rp. 2 & Rp. 25.564.600 \\
\hline Program Pengembangan Sumber Daya Manusia Kesehatan & Rp. 1.341.464.500 & Rp. 1.259.393.422 \\
\hline Program Upaya Pelayanan Kesehatan & Rp. 572.221.600 & Rp. 555.576 .000 \\
\hline TOTAL & Rp. 9.509.710.110 & Rp. 8.238.423.431 \\
\hline
\end{tabular}

Sumber : Dinas Kesehatan Provinsi Sulawesi Utara

Untuk Tahun Anggaran 2017 Pemerintah Provinsi Sulawesi Utara yaitu Badan Pengolah Pajak dan Retribusi, telah menetapkan target penerimaan pajak rokok, yaitu sebesar Rp. 152.887.500.000 dengan jumlah anggaran belanja untuk pendanaan upaya kesehatan masyarakat di Provinsi Sulawesi Utara pada tahun anggaran 2017 adalah sebesar Rp.158.612.742.452 yang diatur oleh Dinas Kesehatan Provinsi Sulawsi Utara.Selanjutnya rancangan APBD dalam kaitannya dengan kebijakan earmarking tax pajak rokok membahas mengenai biaya untuk pendanaan upaya kesehatan masyarakat.

\subsection{Pembahasan}

\subsubsection{Pengaturan Alokasi Dana Pajak Rokok}

Berdasarkan Peraturan Gubernur Sulawesi Utara nomor 16 tahun 2016 Tentang Penetapan Alokasi Sementara Bagi Hasil Pajak Provinsi Kepada Pemerintah Kabupaten/Kota se-Provinsi Sulawesi, pajak rokok termasuk dalam pendapatan asli daerah yang ditransfer oleh pemerintah pusat, karena pajak rokok merupakan pungutan atas cukai rokok. Pajak 
rokok ditransfer oleh pemerintah pusat ke RKUD setiap 3 bulan (triwulan) dikumpulkan oleh Badan Pengelola Pajak dan Retribusi. Dana transfer dalam hal ini adalah pajak rokok, kemudian akan di bagi hasilkan antara kas provinsi dan kabupaten/kota untuk setiap 3 bulan (triwulan) berdasarkan ketentuan. Dana pajak rokok masuk dalam kas daerah bersamaan dengan jenis pendapatan yang lainnya dalam bentuk pendapatan asli daerah, yang kemudian pengelola dananya dilakukan oleh Badan Pengelola Keuangan dan Barang Milik Daerah.

Kaitannya dengan pengalokasian dana pajak atau earmarking tax maka nilai minimal $50 \%$ yang harus dialokasikan dananya untuk upaya kesehatan masyarakat tidak akan terlihat, karena dana pajak rokok yang akan tergabung dalam PAD bersama dengan pendapatan lain pada RKUD. Keberadan besaran minimal 50\% ini diatur dalam Peraturan Gubernur nomor 16 tahun 2016, sehingga dijadikan sebagai jaminan bagi ketersediaan dana untuk peningkatan upaya kesehatan masyarakat. Namun, pembiayaan untuk pengeluaran tersebut juga didasarkan atas keperluan dari daerah, sehingga nominal yang harus dialokasikan bisa lebih.

\subsubsection{Penerimaan Pajak Rokok Provinsi Sulawesi Utara dan Belanja Untuk Pendanaan Upaya Kesehatan Masyarakat}

Dalam "Panduan Umum Penggunaan Pajak Rokok untuk bidang Kesehatan" yang dikeluarkan oleh Kementrian Kesehatan pada tahun 2010, upaya kesehatan masyarakat yang dimaksud yaitu pengendalian konsumsi rokok dan produk tembakau lainnya, penegakan hukum dalam kebijakan Kawasan Tanpa Rokok, dan upaya kesehatan masyarakat. Alokasi dana bagi hasil pajak rokok untuk kesehatan diharapkan dapat mengisi kekurangan di luar belanja rutin daerah. Sesuai dengan hasil penelitian diatas, maka jumlah realisasi penerimaan dan dana bagi hasil pajak rokok serta jumlah belanja dalam mendanai upaya kesehatan masyarakat di Provinsi Sulawesi Utara tahun 2016 sebagai berikut :

Pajak Rokok tahun 2016 : Rp. 107.158.711.896

Untuk Provinsi $: 30 \%$ x Rp. 107.158.711.896=Rp. 32.147.613.569

Untuk Kab/Kota : 70\% x Rp. 107.158.711.896 = Rp. 75.011.098.327

Berikut merupakan rumusan untuk pengalokasian dana pajak atau earmarking tax :

Alokasi Dana Pajak (Earmarking tax)

Provinsi : $50 \%$ x Rp. 32.147.613.569=Rp. 16.073.806.784

Kab/Kota : 50\% x Rp. 75.011.098.327 = Rp. 37.505.549.164

Tabel 5. Penerimaan Pajak Rokok dan Belanja untuk Upaya Kesehatan Masyarakat Provinsi Sulawesi Utara tahun 2016

\begin{tabular}{lc}
\multicolumn{1}{c}{ Penerimaan Pajak Rokok } & Rp. 107.158.711.896 \\
\hline Bagi Hasil Provinsi (30\%) & 32.147 .613 .569 \\
Earmarking tax (50\%) & 16.073 .806 .784 \\
Pengeluaran untuk belanja upaya kesehatan masyarakat & Rp. 8.238 .423 .431 \\
\hline
\end{tabular}

\section{Sumber : Diolah oleh peneliti}

Tabel 5 menunjukkan bahwa besaran pengeluaran untuk belanja dalam hal upaya kesehatan masyarakat untuk tahun 2016 adalah senilai Rp.8.238.423.431. Dana yang digunakan untuk belanja upaya kesehatan masyarakat perhitungannya sebagai berikut :

$$
\begin{aligned}
\text { Presentase }(\%) & =(\text { Rp. 8.238.423.431: Rp. 16.073.806.784) } \times 100 \% \\
& =51,25 \%
\end{aligned}
$$

Dengan demikian, pengeluaran Provinsi Sulawesi Utara untuk upaya kesehatan masyarakat pada tahun 2016 sebesar 51,25\% dari total alokasi dana pajak rokok (earmarking tax). Untuk itu, perbandingan antara alokasi dana pajak rokok dan belanja yang dilakukan Dinas Kesehatan Provinsi Sulawesi Utara belum sesuai dengan peraturan yang diterapkan, karena Dinas Kesehatan belum maksimal belanja dalam menggunakan dana alokasi dari 
penerimaan pajak rokok provinsi. Hanya sebesar Rp. 8.238.423.431 atau 51,25\% dari total earmarking tax yang digunakan untuk upaya kesehatan masyarakat dimana seharusnya Dinas Kesehatan menggunakan semua total dana alokasi tersebut sehingga belanja upaya kesehatan masyarakat dapat mencapai nilai minimalnya yaitu sebesar Rp.16.073.806.784 atau 50\% dari total penerimaan pajak rokok untuk provinsi.

Untuk tahun 2017 ditunjukkan juga target untuk penerimaan pajak rokok dan anggaran untuk belanja upaya kesehatan masyarakat dalam kaitannya dengan pengalokasian dana pajak (earmarking tax) ditunjukkan sebagai berikut :1

Tabel 6 Target Penerimaan Pajak Rokok dan Anggaran untuk Upaya Kesehatan Masyarakat Provinsi Sulawesi Utara tahun 2017

\begin{tabular}{cc}
\hline Target Penerimaan Pajak Rokok & Rp.152.887.500.000 \\
\hline Target Bagi Hasil Provinsi (30\%) & 45.866 .250 .000 \\
Target Earmarking tax (50\%) & 22.933 .125 .000 \\
Rencana Pengeluaran untuk belanja upaya kesehatan & Rp.158.612.742.452 \\
masyarakat & \\
\hline
\end{tabular}

Sumber : (diolah peneliti)

Tabel 6 merupakan gambaran perbandingan antara target penerimaan pajak rokok yang telah dibagi hasilkan bersama dengan target besaran alokasi dana pajak sebesar 50\% dengan jumlah pengeluaran untuk belanja upaya kesehatan masyarakat. Jumlah target dana alokasi (earmarking tax) adalah senilai Rp.22.933.125.000 sedangkan jumlah untuk rencana belanja modal upaya kesehatan masyarakat adalah senilai Rp. 158.612.742.452. Dengan demikian terlihat bahwa jumlah target alokasi dana senilai 22.933.125.000 tersebut sangat kecil jika dibandingkan dengan rencana pengeluaran untuk belanja modal tersebut. Rencana anggaran untuk tahun 2017 mengalami kenaikan yang sangat besar, hal ini diakibatkan dari penambahan beberapa program upaya kesehatan masyarakat. Kurang lebih 8 tambahan program yang dimasukkan Dinas Kesehatan Provinsi Sulawesi Utara dalam APBD tahun 2017.

Akhir tahun 2017 ditargetkan bahwa penerimaan provinsi dari dana bagi hasil pajak rokok yang dialokasikan untuk upaya kesehatan masyarakat sesuai dengan peraturan yang berlaku. Rencana anggaran yang dilakukan oleh Dinas Kesehatan tingkat provinsi melampaui minimal dana yang dialokasikan dari penerimaan pajak rokok untuk provinsi. Dalam hal ini, alokasi dana sebesar 50\% dari penerimaan pajak rokok provinsi akan digunakan secara maksimal melalui belanja Dinas Kesehatan untuk upaya kesehatan masyarakat.

\section{PENUTUP}

\subsection{Kesimpulan}

Berdasarkan hasil penelitian pengalokasian dana pajak atau earmarking tax dari penerimaan pajak rokok diterapkan di Provinsi Sulawesi Utara pada tahun 2015. Pengalokasian tersebut berdasarkan program kegiatan yang dianggarkan oleh Dinas Kesehatan Daerah Provinsi Sulawesi Utara. Pada tahun 2016, berdasarkan realisasi belanja yang dilakukan Dinas Kesehatan dan penerimaan dana bagi hasil pajak rokok untuk provinsi Sulawesi Utara, kebijakan earmarking tax dari penerimaan pajak rokok belum diterapkan sesuai degan peraturan yang berlaku. Hal ini dikarenakan belanja untuk upaya kesehatan masyarakat belum mencapai nilai minimalnya yaitu sebesar 16.073.806.784. Dalam hal ini hanya sebesar Rp.8.238.423.431 atau 51,26\% dari total earmarking tax yang digunakan untuk belanja upaya kesehatan masyarakat. 


\subsection{Saran}

Berdasarkan hasil penelitian pengalokasian dana pajak atau earmarking tax dari penerimaan pajak rokok diterapkan di Provinsi Sulawesi Utara pada tahun 2015. Pengalokasian tersebut berdasarkan program kegiatan yang dianggarkan oleh Dinas Kesehatan Daerah Provinsi Sulawesi Utara. Pada tahun 2016, berdasarkan realisasi belanja yang dilakukan Dinas Kesehatan dan penerimaan dana bagi hasil pajak rokok untuk provinsi Sulawesi Utara, kebijakan earmarking tax dari penerimaan pajak rokok belum diterapkan sesuai degan peraturan yang berlaku. Hal ini dikarenakan belanja untuk upaya kesehatan masyarakat belum mencapai nilai minimalnya yaitu sebesar 16.073.806.784. Dalam hal ini hanya sebesar Rp.8.238.423.431 atau 51,26\% dari total earmarking tax yang digunakan untuk belanja upaya kesehatan masyarakat.

\section{DAFTAR PUSTAKA}

Arikunto, Suharsimi.2013. Prosedur Penelitian Suatu Pendekatan Praktik. RinekaCipta, Jakarta

Bella, Poetri Mutiara. 2010. Analisis Earmarking Tax Atas Pajak Kendaraan Bermotor (Studi Earmarking Tax di DKI Jakarta).

Bird, Richard M. and Joosung Jung. 2005. Earmarking In Theory And Korean Practice. ITP Paper, 0513

Buse, Kent.2005. Making Healt Policy-Understanding Public Health

Clague, Ewan and Joel Gordon. 1939. Earmarking tax Funds For Welfare Purpose. National Conference of Social Work.

Halim, Abdul. 2013. Akuntansi Sektor Publik Akuntansi Keuangan Daerha, Edisi 4. Salemba Empat. Jakarta.

http://www.kppod.org/index.php/en/ diakses tanggal 13 April 2017

Indah, Mita Vajar. 2015. Pelaksanaan Alokasi Dana Bagi Hasil Pajak Rokok Untuk Pelayanan Kesehatan Masyarakat (Studi tentang Implementasi Pasal 31 UndangUndang Nomor 28 Tahun 2009 tentang Pajak Daerah dan Retribusi Daerah di Kabupaten Blitar).

Kementrian Kesehatan. 2010. Panduan Umum Penggunaan Pajak Rokok untuk Bidang Kesehatan

Maharani, Novia Ratna. 2014. Analisis Pendapatan Bagi Hasil Pajak Provinsi Sebagai Upayah Peningkatan Pembangunan Daerah (Studi Pada Dinas Pendapatan Daerah dan Badan Pengolah Keuangan dan Aset Daerah Kabupaten Kediri Tahun 2008-2013.

Permana, Yudha Agung. 2016. Pelaksanaan Pemungutan Pajak Rokok. Skripsi Fakultas Hukum Universitas Lampung. Skripsi diakses melalui . Diakses tanggal

Presiden Republik Indonesia.Undang-Undang No. 28 Tahun 2009 tentang Pajak Daerah dan Retribusi Daerah

Pura, Rahman.2013.Pengantar Akuntansi 1: Pendekatan Siklus Akuntansi.Erlangga : Jakarta.

Rudianto.2012.Pengantar Akuntansi Adaptasi IFRS.Erlangga : Jakarta.

Samudra, Azhari A.( 2004). Pengantar Pajak Daerah dan Retribusi Daerah. Jakarta : Hecca Publishing.

Sugiyono.2013.Metode Penelitian Pendidikan Pendekatan Kuantitatif, Kualitatif, dan R\&D. Bandung:Alfabeta

Suki Hariawan. (2011). Analisis Pengalokasian Anggaran untuk Penerangan Jalan Sebelum dan Sesudah Dikeluarkannya Kebijakan Earmarking Tax atas Pajak Penerangan Jalan di DKI Jakarta. Jakarta : Fakultas Ilmu Sosial dan Ilmu Politik Universitas Indonesia. 